\title{
Stomatopod Crustacea of the KUMEJIMA 2009 Expedition, Japan*
}

\author{
SHANE T. AHYONG \\ Australian Museum, 6 College St., Sydney, NSW 2010, Australia. Email: shane.ahyong@austmus.gov.au \\ * In: Naruse, T., Chan, T.-Y., Tan, H.H., Ahyong, S.T. \& Reimer, J.D. (2012) Scientific Results of the Marine Biodiversity \\ Expedition - KUMEJIMA 2009. Zootaxa, 3367, 1-280.
}

\begin{abstract}
The stomatopod Crustacea collected during the KUMEJIMA 2009 expedition to Kume Island, Ryukyu Islands, southern Japan, are reported. The collection comprises 20 species from three superfamilies, six families and 15 genera. Of these 20 species, 10 are new records for Japan, of which one species, Gonodactylellus kume, is new to science. The new species ranges from Japan to northern Australia and is most similar to G. micronesicus (Manning, 1971), differing in the colour of the meral spot of raptorial claw and shape of the pleopod 1 endopod of adult males. The identities of Alima angusta Dana, 1852, and A. gracilis H. Milne Edwards, 1837, as junior synonyms of A. neptuni Linneaus, 1758, are fixed by neotype selection. A checklist of the 68 species of Stomatopoda recorded from Japan is provided.
\end{abstract}

Keywords: Stomatopoda, Gonodactylellus, Alima, Kume, Ryukyus, Japan, Australia, mantis shrimp

\section{Introduction}

In November 2009, the KUMEJIMA 2009 expedition explored coral reefs and adjacent environments around Kume Island, Ryukyu Islands, southern Japan. Sampling was conducted using a variety methods including dredge, trawl and on SCUBA. Prior to the present study, 58 species of Stomatopoda were known from Japanese waters, with only 13 species reported from the Ryukyus (Komai 1927, 1940; Moosa 1989; Ahyong et al. 2000; Ahyong 2001; Osawa et al. 2004; Ahyong et al. 2008). The present report details the Stomatopoda collected from Kume Island, comprising 20 species of which one is new to science, 10 are first records for Japanese waters and 15 are first records for the Ryukyus; all are first records for Kume Island.

\section{Materials and methods}

Morphological terminology follows Ahyong (2001) and Ahyong et al. (2008). All specimen measurements are given in mm. Total length (TL) is measured along the dorsal midline from the tip of the rostral plate to the apices of the submedian teeth of the telson. Carapace length $(C L)$ is measured along the dorsal midline of the carapace and excludes the rostral plate. The abdominal-width carapace-length index (AWCLI) is given as $100 \times$ (width of abdominal somite 5)/CL. Specimens are deposited in the Ryukyu University Museum, Fujukan, Okinawa (RUMF), the Australian Museum, Sydney (AM), the Western Australian Museum, Perth (WAM), the Raffles Museum of Biodiversity Research, National University of Singapore (ZRC) and the National Museum of Natural History, Smithsonian Institution, Washington D.C. (USNM). New records for Japan are indicated (*). New records for the Ryukyu Islands are indicated (\#)

\section{SYSTEMATICS}

GONODACTYLOIDEA Giesbrecht, 1910

GONODACTYLIDAE Giesbrecht, 1910 


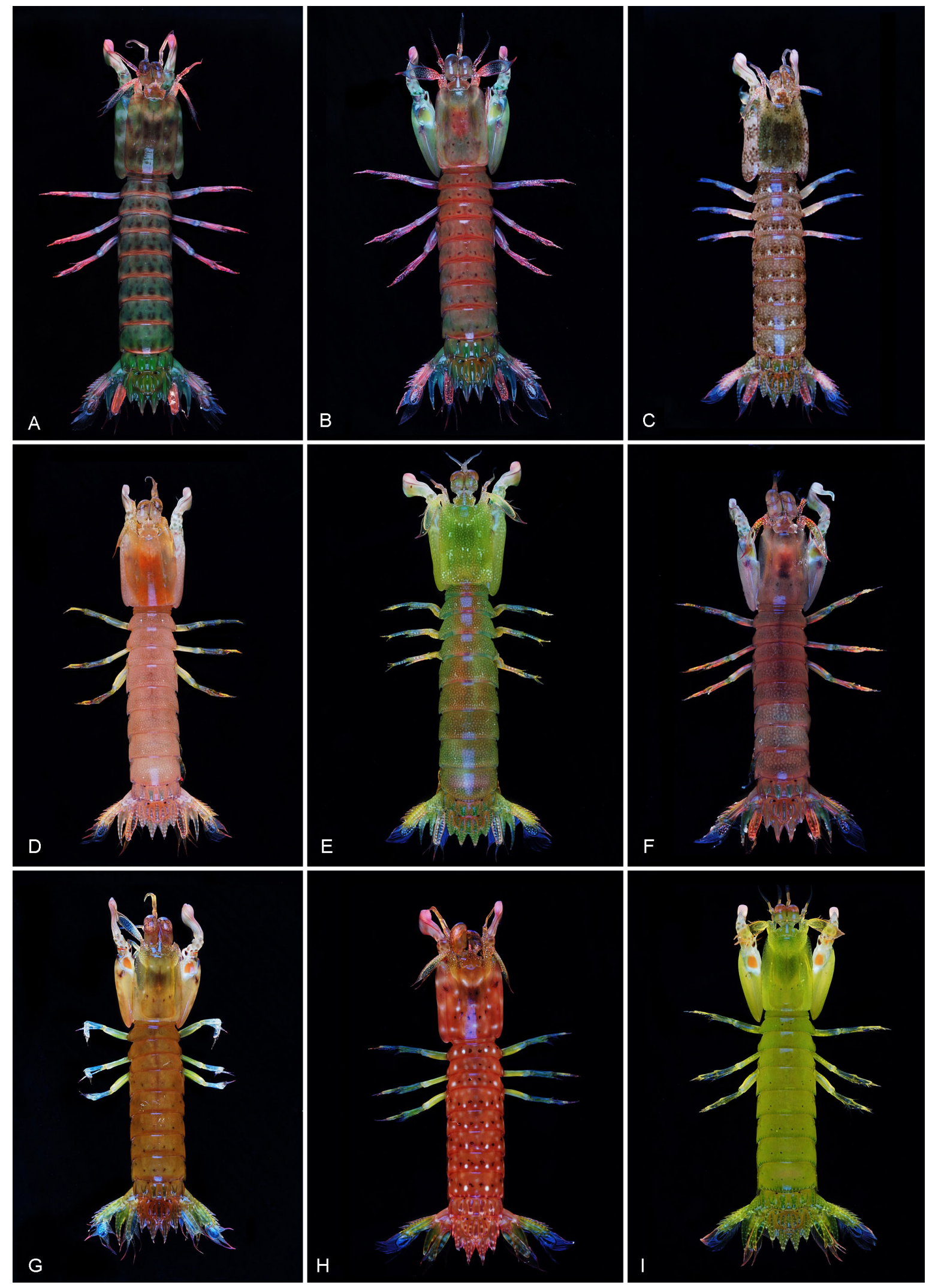

FIGURE 1. Colour variation in Gonodactylaceus. Gonodactylaceus falcatus (Forskål, 1775): A, male TL 41 mm (RUMF-ZC01246); B, male TL 33 mm (RUMF-ZC-01241); C, male TL 33 mm (AM P87561); D, female TL 37 mm (RUMF-ZC-01246); E, female TL 42 mm (RUMF-ZC-01246); F, female 26 mm (RUMF-ZC-01246). Gonodactylaceus glabrous (Brooks, 1886): G, male TL 25 mm (RUMF-ZC-01249); H, female TL 28 mm (RUMF-ZC-01250); I, female TL 40 mm (RUMF-ZC-01253). 


\section{Gonodactylaceus falcatus (Forskål, 1775)}

(Fig. 1A-F)

Cancer falcatus Forskål, 1775: 96 [type locality: Djeddah, Red Sea, by neotype selection (Manning \& Lewinsohn 1981)].

Gonodactylus glabrous. — Fukuda 1908: 511, pl. 2, fig. 2; 1910: 141; 1913: 72. — Komai 1927: 340 [not G. glabrous (Brooks, 1886)].

Gonodactylus falcatus. — Utinomi 1956: 92, pl. 46, fig. 5 (colour plate). — Manning 1965: 260. — Moosa 1989: 224.

Gonodactylus chiragra var. mutatus Lanchester, 1903: 450 [type locality: Furnadu Velu, Miladumadulu Atoll, Maldive Islands, $\left.6^{\circ} 00^{\prime} \mathrm{N}, 73^{\circ} 10^{\prime} \mathrm{E}\right]$.

Gonodactylus glaber var. rotundus Borradaile, 1907: 211-212, pl. 22: fig. 2 [type locality: Coetivy, Seychelles, $7^{\circ} 08^{\prime} \mathrm{S}$, $56^{\circ} 16^{\prime} \mathrm{E}$, and Zanzibar, $\left.6^{\circ} 10^{\prime} \mathrm{S}, 39^{\circ} 12^{\prime} \mathrm{E}\right]$.

Gonodactylus insularis Manning \& Reaka, 1982: 347-351, figs. 1, 2 [type locality: Kidrenen Island, Enewetak, 11²2'50"N, 162¹0'30"E]. — Moosa 1989: 224.

Gonodactylus aloha Manning \& Reaka, 1981a: 190-200, figs. 1-3 [type locality: Oahu, Hawaiian Islands].

Gonodactylus siamensis Manning \& Reaka, 1981b: 479-482, fig. 1 [type locality: Sattahip, Gulf of Thailand, $12^{\circ} 40^{\prime} \mathrm{N}$ $\left.100^{\circ} 52^{\prime} \mathrm{E}\right]$.

Gonodactylus takedai Moosa, 1989: 225-226, fig. 1 [type locality: Miyanohama, Chichi-jima, Ogasawara Islands].

Gonodactylaceus gravieri Manning, 1995: 42, 43, 46-48, fig. 13 [type locality: Poulo Condore, Vietnam].

Gonodactylaceus falcatus. — Ahyong 2001: 35-38, fig. 17. — Osawa et al. 2004: 7. — Hamano, 2005: 12, 21-22, fig. 2-5a-d. - Ahyong 2007: 334; 2012: 19-22, figs 7, 8.

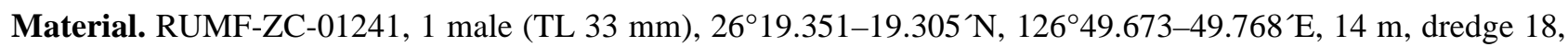
11 Nov 2009; RUMF-ZC-01242, 2 males (TL 12, $19 \mathrm{~mm}$ ), 1 female (TL $19 \mathrm{~mm}$ ), 26⒚907-20.056`N, 12643.191-42.622E, 67.5-76.0 m, dead coral rubble, dredge 45, 16 Nov 2009; RUMF-ZC-01243, 1 male (TL 32 $\mathrm{mm}), 26^{\circ} 20.409-20.018^{\prime} \mathrm{N} 126^{\circ} 49.675-49.224^{`} \mathrm{E}, 5.1-4.5 \mathrm{~m}$, dead coral branches, rubble, dredge 52, 17 Nov 2009; RUMF-ZC-01244, 1 male (TL $20 \mathrm{~mm}$ ), 1 female (TL $27 \mathrm{~mm}$ ), 26¹9.456-19.400`N, 126 49.450-49.182`E, 4.5-9.0 m, dead coral blocks, trawl 54, 17 Nov 2009; RUMF-ZC-01245, 1 female (TL $18 \mathrm{~mm}$ ), 26 $6^{\circ} 19.442-19.378^{`} \mathrm{~N}, 126^{\circ} 49.211-49.198^{`} \mathrm{E}, 4.7-9.5 \mathrm{~m}$, dredge 55, 17 Nov 2009; RUMF-ZC-01246, 2 males (TL 21-41 mm), 4 females (TL 26-42 mm), 26 $6^{\circ} 19.360^{`} \mathrm{~N} 26^{\circ} 19.294^{`} \mathrm{~N}, 126^{\circ} 49.204^{`} \mathrm{E} 126^{\circ} 49.192^{\prime} \mathrm{E}, 7.5-4.7 \mathrm{~m}$, dead coral blocks, rubble, dredge 56, 17 Nov 2009; RUMF-ZC-01247, 1 male (TL $14 \mathrm{~mm}$ ), 26 ${ }^{\circ} 19.622-19.424^{`} \mathrm{~N}$, 126 49.511-49.450`E, 9.4-12.5 m, rubble, seaweed, dredge 57, 17 Nov 2009; RUMF-ZC-01248, 1 female (TL 18 $\mathrm{mm}), 26^{\circ} 19.553-19.463^{`} \mathrm{~N}, 126^{\circ} 49.510-49.491^{`} \mathrm{E}, 9.1-13.3 \mathrm{~m}$, sand, dredge 58, 17 Nov 2011; AM P87561, 1 male (TL $33 \mathrm{~mm}$ ), 1 female (TL $26 \mathrm{~mm}$ ), 26 $20.307-20.158^{\circ} \mathrm{N}, 126^{\circ} 49.360-49.334^{\prime} \mathrm{E}, 5.1-6.4 \mathrm{~m}$, trawl 59, 18 Nov 2009; ZRC 2011.0823, 2 females (TL 10, 27 mm), 26¹9.095-18.898`N, 12649.008-48.969`E, 10.1-17.1 m, sand, mud, dredge 68, 19 Nov 2009.

Remarks. Gonodactylaceus falcatus is widely distributed in the Indo-West Pacific and has already been reported from Japanese waters, including the Ryukyus. All males exceeding TL $12 \mathrm{~mm}$ exhibit sexually modified endopods on pleopod 1 . The overall body colouration of G. falcatus is highly variable but also sexually dimorphic. In males, each somite usually has a transverse row of 4-6 dark spots or patches that become proportionally larger with increasing size; females lack these dark patches; the meral spot of raptorial claw in both sexes is yellow (Fig. 1A-F).

Distribution. Western Indian Ocean to Hawaii (introduced) including Australia, New Zealand and Japan; intertidal to at least $23 \mathrm{~m}$ (Ahyong 2001).

\section{Gonodactylaceus glabrous (Brooks, 1886)*\#}

(Fig. 1G-I)

Gonodactylus glabrous Brooks, 1886: 22, 64, pl. 14: fig. 5, pl. 15: figs. 7, 9 [type locality: Samboangan reefs, Philippines]. Gonodactylus bossorotundus Roxas \& Estampador, 1930: 94, 122, pl. 6: figs. 1, 2 [type locality: Samboangan reefs, Philippines, by neotype designation (Ahyong 2001)].

Gonodactylus chiragra var. crescentus Roxas \& Estampador, 1930: 94, 120, pl. 5: fig. 3 [type locality: Samboangan reefs, Philippines, by neotype designation (Ahyong 2001)].

Gonodactylaceus glabrous. - Ahyong 2001: 38-40, fig. 18.

Material. RUMF-ZC-01249, 1 male (TL $25 \mathrm{~mm}$ ), 26¹9.714-19.579`N, 126 ${ }^{\circ} 45.649-45.707^{`} \mathrm{E}, 17.9-42.5 \mathrm{~m}$, rubble, dredge 44, 14 Nov 2009; RUMF-ZC-01250, 1 female (TL $28 \mathrm{~mm}$ ), 26¹9.449-19.478`N, 
126 45.748-45.800`E, 8.9-9.3 m, dead coral branches, rubble, dredge 51, 16 Nov 2009; RUMF-ZC-01251, 1 female (TL $39 \mathrm{~mm}$ ), 26 $20.409-20.018^{\prime} \mathrm{N} 126^{\circ} 49.675-49.224^{\prime} \mathrm{E}, 5.1-4.5 \mathrm{~m}$, dead coral branches, rubble, dredge 52, 17 Nov 2009; RUMF-ZC-01252, 1 female (TL $29 \mathrm{~mm}$ ), 26 $19.456-19.400^{`} \mathrm{~N}, 126^{\circ} 49.450-49.182^{`} \mathrm{E}, 4.5-9.0$ m, dead coral blocks, trawl 54, 17 Nov 2009; RUMF-ZC-01253, 1 female (TL 40 mm), 26 20.307-20.158` N, 126 49.360-49.334E, 5.1-6.4 m, trawl 59, 18 Nov 2009; AM P87562, 1 female (TL $39 \mathrm{~mm}$ ), $26^{\circ} 20.307-20.158^{`} \mathrm{~N}, 126^{\circ} 49.360-49.334^{`} \mathrm{E}, 5.1-6.4 \mathrm{~m}$, trawl 59, 18 Nov 2009; ZRC 2011.0820, 2 females (TL $18-19 \mathrm{~mm}$ ), Koukou-mae (in front of high school), $26^{\circ} 19.885^{\prime} \mathrm{N}, 126^{\circ} 45.616^{`} \mathrm{E},<4 \mathrm{~m}$, mud, dead coral rubble, yabby pump, dive 16, 14 Nov 2009.

Remarks. The specimens represent the first record of G. glabrous sensu stricto from Japanese waters. Previous records of G. glabrous from Japan (e.g., Fukuda 1908, 1910, 1913) are based on G. falcatus. Gonodactylaceus glabrous exhibits highly variable body patterning similar to that of $G$. falcatus reported above, but the meral spot of raptorial claw is orange rather than yellow (Fig. 1G-I).

Distribution. Western Australia, Indonesia, the Philippines and now from Japanese waters; intertidal to $42.5 \mathrm{~m}$.

\section{Gonodactylellus annularis Erdmann \& Manning, 1998*\# \\ (Fig. 2A)}

Gonodactylellus annularis Erdmann \& Manning, 1998: 617-618, fig. 1b [type locality: Kapoposang, Spermonde, Indonesia]. — Ahyong 2001: 48-49, fig. 22. — Ahyong \& Naiyanetr 2002: 283.

Material. RUMF-ZC-01255, 1 male (TL $14 \mathrm{~mm}$ ), 1 female (TL $16 \mathrm{~mm}$ ), 26 $6^{\circ} 19.789-19.733^{\prime} \mathrm{N}$, 126 52.103-52.070'E, 18.7-20.5 m, rubble, dredge 61, 18 Nov 2009; RUMF-ZC-01256, 1 female (TL $9 \mathrm{~mm}$ ), $26^{\circ} 19.517-19.513^{`} \mathrm{~N}, 126^{\circ} 45.797-45.782^{\circ} \mathrm{E}, 9.6-13.2 \mathrm{~m}$, dead coral branches, rubble, dredge 50, 16 Nov 2009; RUMF-ZC-01257, 1 male (TL 9 mm), 26¹9.456-19.400`N, 12649.450-49.182`E, 4.5-9.0 m, dead coral blocks, trawl 54, 17 Nov 2009.

Remarks. The specimens agree well with published accounts and represent the first record from Japanese waters. The ocular scales are partially fused, having a small median emargination. The $9 \mathrm{~mm}$ male (RUMF-ZC01257) is a juvenile, having short penes and an unmodified pleopod 1 endopod.

Distribution. Andaman Sea, Thailand to Indonesia, northern Australia and now from Kume, southern Japan; $4.5-20.5 \mathrm{~m}$.

\section{Gonodactylellus kume sp. nov.*\#}

(Fig. 2B-F, 3)

Gonodactylus incipiens. — Moosa, 1991: 158 [part, not G. incipiens (Lanchester, 1903)].

Gonodactylellus micronesicus. - Ahyong 2001: 57, fig. 27A-I [part, Indian Ocean and Lizard Island specimens only]; 2007: 334. [Not G. micronesicus (Manning, 1971)]

Type material. HOLOTYPE: RUMF-ZC-01262, male (TL $22 \mathrm{~mm}$ ), $26^{\circ} 19.449-19.478^{`} \mathrm{~N}, 126^{\circ} 45.748-45.800^{`} \mathrm{E}$, 8.9-9.3 m, dead coral branches, rubble, dredge 51, 16 Nov 2009. PARATYPES: RUMF-ZC-01272, 1 male (TL 17 $\mathrm{mm}), 26^{\circ} 19.449-19.478^{\prime} \mathrm{N}, 126^{\circ} 45.748-45.800^{\prime} \mathrm{E}, 8.9-9.3 \mathrm{~m}$, dead coral branches, rubble, dredge 51, 16 Nov 2009; RUMF-ZC-01258, 1 female (TL 19 mm), Umagai, $26^{\circ} 20.769^{`} \mathrm{~N}, 126^{\circ} 51.506^{\prime} \mathrm{E}$, 5-50 m, Dive 1, 9 Nov 2009; RUMF-ZC-01259, 1 male (TL $17 \mathrm{~mm}$ ), Nanguchi, $26^{\circ} 18.536^{`} \mathrm{~N}, 126^{\circ} 50.402^{\circ} \mathrm{E},<25 \mathrm{~m}$, dead coral rubble, reef-end, dive 8, 11 Nov 2009; RUMF-ZC-01260, 1 male (TL $19 \mathrm{~mm}$ ), 1 female (TL $20 \mathrm{~mm}$ ), 26 ${ }^{\circ} 18.330-18.351^{\prime} \mathrm{N}$, $126^{\circ} 49.730-49.734^{\prime} \mathrm{E}, 27-28 \mathrm{~m}, 27-28 \mathrm{~m}$, trawl 15, 11 Nov 2009; RUMF-ZC-01261, 1 female (TL $19 \mathrm{~mm}$ ), Umagai, $26^{\circ} 20.769^{\prime} \mathrm{N}, 126^{\circ} 51.506^{\prime} \mathrm{E}, 55 \mathrm{~m}$, dive 1b, 9 Nov 2009; RUMF-ZC-01267, 1 male (TL $16 \mathrm{~mm}$ ), Tengokuto-Zigoku, $26^{\circ} 19.421^{`} \mathrm{~N}, 126^{\circ} 45.733^{`} \mathrm{E}, 6-8 \mathrm{~m}$, dive 37, 19 Nov 2009; AM P87563, 2 males (TL 15-21 mm), 26 $6^{\circ} 19.714-19.579^{\prime} \mathrm{N}, 126^{\circ} 45.649-45.707^{\prime} \mathrm{E}, 17.9-42.5 \mathrm{~m}$, rubble, dredge 44, 14 Nov 2009; RUMF-ZC-01263, 1 female (TL $16 \mathrm{~mm}$ ), 26 $6^{\circ} 19.502-19.494^{\prime} \mathrm{N}, 126^{\circ} 45.570-45.796^{`} \mathrm{E}, 50-11.4 \mathrm{~m}$, dead coral branches, rubble, dredge 49, 16 Nov 2009; ZRC 2011.0824, 1 male (TL $17 \mathrm{~mm}$ ), 1 female (TL $14 \mathrm{~mm}$ ), 26019.517-19.513 $\mathrm{N}$, 126 45.797-45.782E, 9.6-13.2 m, dead coral branches, rubble, dredge 50, 16 Nov 2009; AM P87564, 1 female (TL $21 \mathrm{~mm}$; with gastropod Caledoniella and rhizocephalan parasites), Imazuni, 53 m, SCUBA, 10 Nov 2009. 
Other material. AUSTRALIA: AM P84085, 1 male (TL $16 \mathrm{~mm}$ ), Wall of Fish, Yonge Reef, outer Great

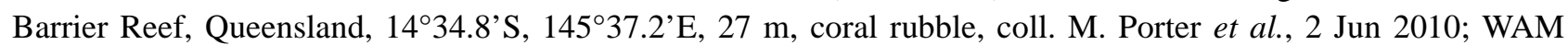
C45805, 1 female (TL 22 mm), Cassini, 135․ ${ }^{\circ} .094^{\prime} \mathrm{S}, 1^{2} 5^{\circ} 37.447^{\prime} \mathrm{E}, 2 \mathrm{~m}$, st. 37/K10-T4, coll. Skipton, 18 Oct 2010. PAPUA NEW GUINEA: AM P64464, 1 female (TL 18 mm, with gastropod Caledoniella), Horseshoe Reef, Bootless Inlet, $9^{\circ} 30.5^{\prime} \mathrm{S} 147^{\circ} 15.5^{\prime} \mathrm{E}$, base of reef slope, outer face, coral rubble with some Padina, $30 \mathrm{~m}$, PNG-21, coll. S. Arnam \& J. Lowry, 28 Oct 1980; AM P64468, 1 female (TL 15 mm), north end of Kiriwinna Island, Papua New Guinea, poison station, coll. Collette, Goldman \& Palmer, 7 Jun 1970. SOLOMON ISLANDS: AM P64465, 1 male (TL $10 \mathrm{~mm}$ ), between Tandai \& Koilo Points, Guadalcanal, Solomon Islands, $09^{\circ} 22.5^{\prime} \mathrm{S} 159^{\circ} 52.2^{\prime} \mathrm{E}$, airlift over small encrusted coral heads on grey sand, 15 m, SI-2, coll. R. Springthorpe 24 Sep 1991.

Diagnosis. Ocular scales separate, subtriangular, apices rounded. Rostral plate basal portion anterolateral angles rounded; lateral margins divergent anteriorly. Raptorial claw dactylus without proximal notch in adults. Thoracic somite 6 lateral processes truncate ventrally, wider than that of thoracic somite 7. Pleopod 1 endopod with indistinct lateral lobe on posterior endite; lateral lobe narrow, small, margin continuous with or hardly breaking from general outline of distal 'endite'. Telson surface without dorsal spinules; intermediate teeth apices extending posteriorly well beyond apices of intermediate denticles; intermediate carina extending anteriorly beyond midlength of accessory median carina; emargination between submedian and intermediate teeth acute; lateral teeth indicated by a shallow notch; median carina with small posterior tubercle or spinule, otherwise unarmed dorsally; accessory median carinae unarmed, extending anteriorly to about midlength of median carina or to posterior onethird in males with inflated median carina; anterior submedian carinae extending anteriorly as far as base of median carina; knob present.

Description. Eyes elongate; cornea subconical. Ocular scales separate, subtriangular, apices rounded. Antennular peduncle length $0.63-0.73 \mathrm{CL}$. Antennal scale length $0.38-0.42 \mathrm{CL}$.

Rostral plate as long as wide or longer than wide; basal portion with transverse or slightly sloping posteriorly; anterolateral angles rounded; lateral margins divergent anteriorly; median spine longer than base, without ventral keel.

Raptorial claw dactylus without proximal notch on outer margin in adults; propodus with proximal movable spine, opposable margin sparsely pectinate proximally.

Mandibular palp 3-segmented.

Thoracic somite 6 lateral processes truncate ventrally, wider than that of thoracic somite 7 . Thoracic somite 8 anterolateral margin rounded; sternal keel obsolete.

Pleopod 1 endopod with indistinct lateral lobe on posterior 'endite'; lateral lobe narrow, small, usually evenly rounded (obtusely angular in holotype), margin continuous with or hardly breaking from general outline of distal 'endite', demarcated at most by small notch.

Abdominal somite 1-5 posterolateral angles unarmed. AWCLI 688-752. Abdominal somite 6 with posteriorly armed submedian, intermediate and lateral bosses.

Telson as wide as or wider than long, surface without dorsal spinules; with 10-14 spiniform submedian denticles. Submedian teeth unarmed dorsally, dorsal carina relatively slender. Intermediate teeth distinct, apices sharp, extending posteriorly well beyond apices of intermediate denticles; intermediate carina slender, extending anteriorly beyond midlength of accessory median carina; emargination between submedian and intermediate teeth acute. Lateral teeth indicated by a shallow notch, apex angular to blunt, not projecting well off margin of telson. Median carina more strongly inflated in males than in females; with small posterior tubercle or spinule, otherwise unarmed dorsally. Accessory median carinae unarmed, extending anteriorly to about midlength of median carina or to posterior one-third in males with inflated median carina. Anterior submedian carinae smooth, unarmed, straight or slightly arcuate, extending anteriorly as far as base of median carina. Knob present. Telson ventral surface without carinae on submedian or intermediate teeth.

Uropodal protopod terminal spines with outer spine longer. Uropodal exopod proximal segment outer margin with 9-11 movable spines, distalmost spine exceeding apex of distal segment; inner margin setose; distal margin with ventral spine; exopod distal segment rounded, entire margin setose. Uropodal endopod narrow, length 3.29-3.71 breadth; with low dorsolateral carina; entire margin setose.

Colour in life. (Fig. 2B-F) Overall body colour variable, ranging from mottled pale green to red. Raptorial claw dactylus pink-orange; meral spot red.

Measurements. Males ( $\mathrm{n}=10)$ TL 10-22 mm, females $(\mathrm{n}=9)$ TL 14-22 mm. Other measurements of holotype: CL $4.6 \mathrm{~mm}$, antennular peduncle $3.1 \mathrm{~mm}$, antennal scale $1.8 \mathrm{~mm}$, abdominal somite 5 width $3.2 \mathrm{~mm}$. 


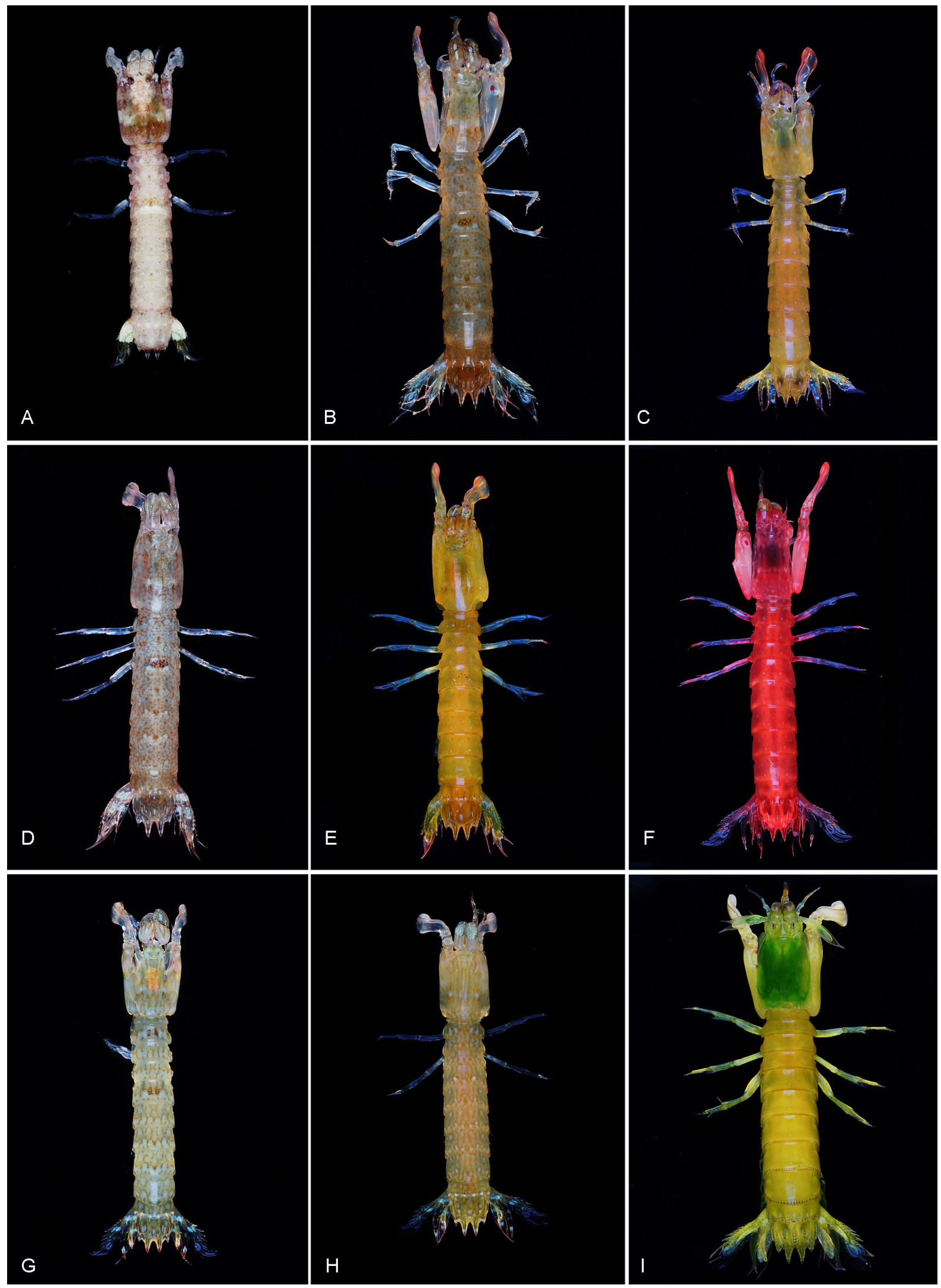

FIGURE 2. A, Gonodactylellus annularis Erdmann \& Manning, 1998, female TL 16 mm (RUMF-ZC-01255); B-F, Gonodactylellus kume sp. nov., (B) female paratype TL $19 \mathrm{~mm}$ (RUMF-ZC-01258), (C) female paratype TL $19 \mathrm{~mm}$, (RUMFZC-01261), (D) male paratype TL $17 \mathrm{~mm}$ (RUMF-ZC-01259), (E) male holotype TL $22 \mathrm{~mm}$ (RUMF-ZC-01262), (F) male paratype TL 19 mm (RUMF-ZC-01260); G-H, Gonodactylellus rubriguttatus Erdmann \& Manning, 1998, female TL 16 mm (ZRC 2011. 0822), female TL 27 mm (RUMF-ZC-01266); I, Gonodactylellus viridis (Serène, 1954), female TL $37 \mathrm{~mm}$ (RUMF-ZC-01270). 


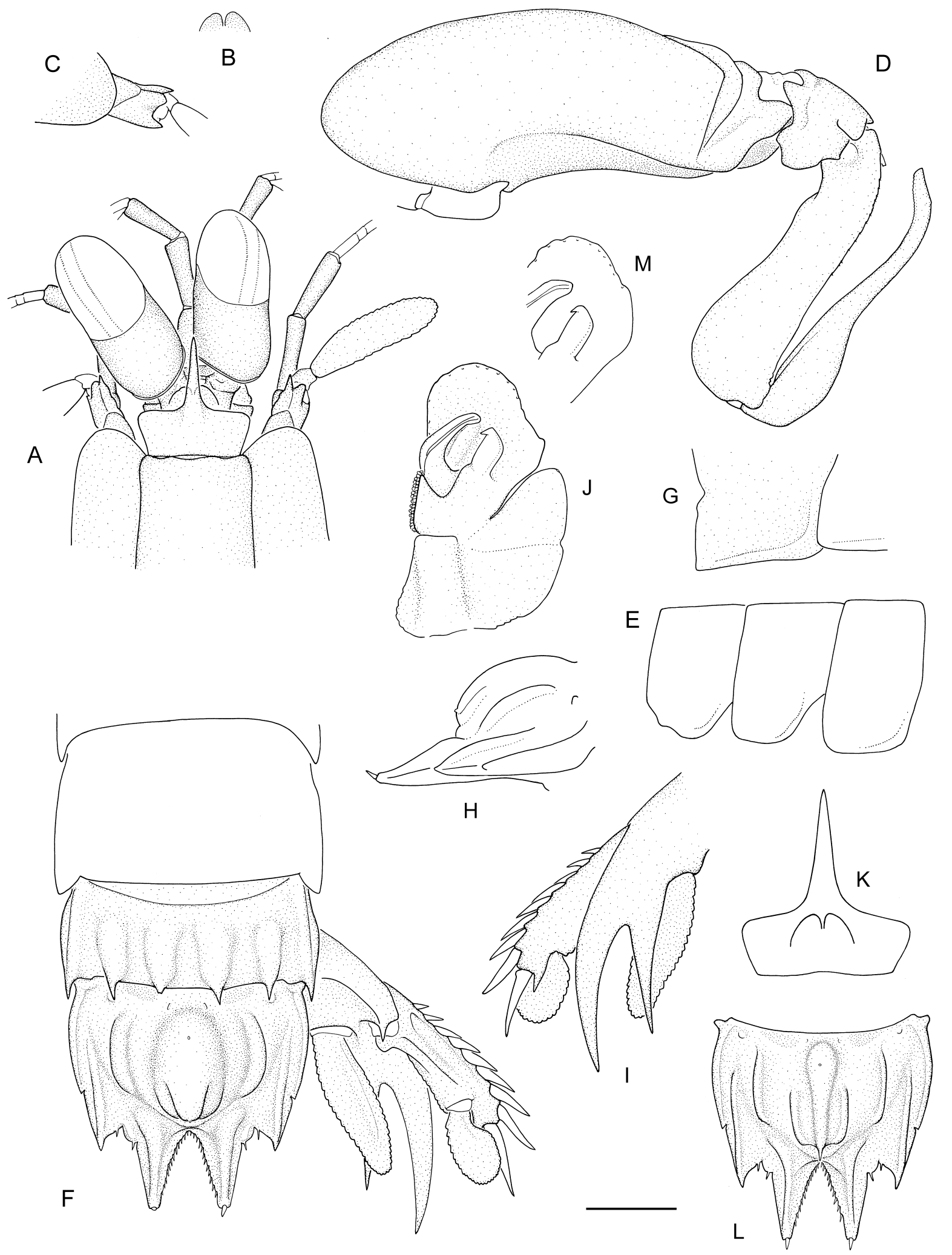

FIGURE 3. Gonodactylellus kume sp. nov. A-J, male holotype, TL $22 \mathrm{~mm}$ (RUMF-ZC-01262). K, male paratype, TL $14 \mathrm{~mm}$ (ZRC 2011.0824). L, female paratype, TL $21 \mathrm{~mm}$ (AM P87564). M, male paratype, TL $21 \mathrm{~mm}$ (AM P87564). A, anterior cephalothorax. B, ocular scales. C, right antennal protopod. D, right raptorial claw. E, thoracic somites 6-8, right lateral view. F, posterior abdominal somites, telson and right uropod. G, abdominal somites 4-5, right posterolateral angles. H, telson, right lateral view. I, right uropod, ventral view. J, right pleopod 1 endopod, anterior view. K, outline of rostral plate and ocular scales. $\mathrm{L}$, telson. $\mathrm{M}$, distolateral margin of right pleopod 1 endopod, anterior view. Scale A-I, L = $1.0 \mathrm{~mm} ; \mathrm{J}-\mathrm{K}, \mathrm{M}=0.5 \mathrm{~mm}$. 
Etymology. Named after the expedition and type locality, Kume; used as a noun in apposition.

Remarks. Prior to this study, Gonodactylellus Manning, 1995, contained 21 species from the Indo-West Pacific (Ahyong 2001, 2008, 2012; Ahyong \& Erdmann 2007). Gonodactylellus kume sp. nov. most closely resembles G. micronesicus (Manning, 1971) and G. rubriguttatus Erdmann \& Manning, 1998, sharing unarmed accessory median carinae on the telson, which extend anteriorly to near the midlength of the median carina. The separate instead of fused ocular scales distinguish G. kume and G. micronesicus from G. rubriguttatus. The red instead of white meral spot of the raptorial claw distinguishes G. kume and G. rubriguttatus from G. micronesicus. Male G. kume differ from both G. micronesicus and G. rubriguttatus in having an indistinct lobe on the outer margin of the distal 'endite' of the pleopod 1 endopod. The lateral lobe in G. kume is narrow, with its margin continuous with or hardly breaking from the general outline of the distal 'endite' (demarcated at most by small notch; Fig. 3J, M)), rather than projecting laterally as a prominent flap (strongly demarcated by a deep notch) as in $G$. rubriguttatus and G. micronesicus (see Ahyong 2001: 29J; 2002a: fig. 3F). Whilst both sexes of G. kume differ from G. rubriguttatus by the separate instead of fused ocular scales, specimens of female G. kume in which the colour is faded will be difficult to distinguish from G. micronesicus.

As in other species of Gonodactylellus, the telson carinae of adults are sexually dimorphic. Telson carinae in females and early adult males are relatively slender, whereas those of large males are more inflated, with the median carina tumid, largely obscuring the accessory median carinae. In these large males, the anterior ends of the accessory median carinae are subsumed by the median carina and thus reach anteriorly only as far as the posterior one-third instead of the midlength of the median carina. Males in the present series range from TL 10-21 mm; all have fully developed penes and modified pleopod 1 endopods. The proximal notch on the outer margin of the dactylus of the raptorial claw is distinct in juveniles, faint or indistinct by TL $15 \mathrm{~mm}$, and absent above TL $15 \mathrm{~mm}$. Two females (TL $18 \mathrm{~mm}$, AM P64464; TL $21 \mathrm{~mm}$, AM P87564) are parasitized by the gastropod mollusc, Caledoniella montrouzieri Souverbie, 1869.

Records of G. micronesicus from Western Australia, the Cocos-Keeling Islands and New Caledonia (Ahyong 2001, 2007) are referrable to G. kume sp. nov. Queensland specimens reported by Ahyong (2001) as G. micronesicus are referrable to two species: G. kume (Lizard Island specimens) and an undescribed species of Gonodactylellus currently under study (non-Lizard Island specimens). This revised distribution of G. micronesicus suggests that the species favours oceanic island habitats in the central-western to central Pacific, from Micronesia, Guam and French Polynesia. In contrast, G. kume occurs along the western margins of the western Pacific (between Japan and Australia) to the eastern Indian Ocean (between northwestern Australia and the Cocos-Keeling Islands).

Habitat. Coral reef amongst rubble; 8.9-55 m.

Distribution. Western Pacific to eastern Indian Ocean, from southern Japan to Papua New Guinea, the Solomon Islands, New Caledonia and northern Australia.

\section{Gonodactylellus rubriguttatus Erdmann \& Manning, 1998*\#}

(Fig. 2G-H)

Gonodactylus incipiens. — Moosa, 1991: 158 [part].

Gonodactylellus rubriguttatus Erdmann and Manning, 1998: 619-620, fig. 1d [type locality: Tanjung Torosie, Komodo/Rinca, Indonesia]. - Ahyong 2001: 60-61, fig. 29; 2007: 334.

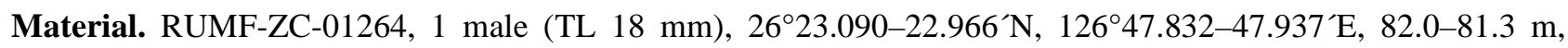
rubble, trawl 7, 10 Nov 2009; RUMF-ZC-01265, 1 female (TL $13 \mathrm{~mm}$ ), 26⒉806-22.670`N, $126^{\circ} 48.035-48.327^{\prime} \mathrm{E}, 68 \mathrm{~m}$, dredge 11, 10 Nov 2009; RUMF-ZC-01266, 1 female (TL $24 \mathrm{~mm}$ ), $26^{\circ} 16.961-17.028^{`} \mathrm{~N}, 126^{\circ} 52.508-51.952^{`} \mathrm{E}, 136-126 \mathrm{~m}$, trawl 27, 12 Nov 2009; RUMF-ZC-01268, 1 female (TL $19 \mathrm{~mm}), 26^{\circ} 16.775-16.759^{\prime} \mathrm{N}, 126^{\circ} 48.050-47.810^{\prime} \mathrm{E}, 67.3-73.3 \mathrm{~m}$, iron anchor, dead coral blocks, rubble, trawl 32, 13 Nov 2009; AM P87565, 2 males (TL 17-23 mm), 1 female (TL $23 \mathrm{~mm}$ ), 26¹9.907-20.056’ N, 126 43.191-42.622E, 67.5-76 m, dead coral blocks, rubble, trawl 45, 16 Nov 2009; ZRC 2011.0821, 1 male (TL $24 \mathrm{~mm}$ ), $26^{\circ} 19.553-19.463^{\prime} \mathrm{N}, 1^{\circ} 49.510-49.491^{\prime} \mathrm{E}, 9.1-13.3 \mathrm{~m}$, sand, dredge 58, 17 Nov 2011 ; ZRC 2011. 0822, 1 female (TL $16 \mathrm{~mm}$ ), 26¹9.672-19.698` N, 12643.328-42.957`E, 101-93.2 m, rubble, dredge 76, 19 Nov 2009; RUMF-ZC-01269, 1 female (TL 14 mm), 26º $15.271-15.475^{\prime} \mathrm{N}, 1^{\circ} 6^{\circ} 47.659-47.224^{\prime} \mathrm{E}, 116-125 \mathrm{~m}$, shells, rubble, dredge 81, 20 Nov 2009. 
Remarks. The present specimens are the first record of G. rubriguttatus from Japanese waters. The lateral lobe of the distal endite of pleopod 1 is well-developed in all males examined.

Distribution. Northern Australia, Indonesia, New Caledonia and now from Japanese waters; 6-136 m.

\section{Gonodactylellus viridis (Serène, 1954)}

(Fig. 2I)

Gonodactylus chiragra var. viridis Serène, 1954: 6, 7, 10, 74, 75, 76, 87, fig. 13-3 (type locality: Cauda Bay, Vietnam). Gonodactylus viridis. — Manning 1978: 4, fig. 2a-c. — Moosa 1989: 226.

Gonodactylellus incipiens. - Manning 1995: 63: fig. 24 [TL $30 \mathrm{~mm}$ female only, not G. incipiens (Lanchester, 1903)]. Gonodactylinus viridis. — Ahyong \& Norrington 1997: 100. — Manning 1995: 66-68, figs. 8c, d, 9c, 10e, 11c, 25a. Gonodactylellus viridis. — Ahyong 2001: 63-64, fig. 31. — Hamano 2005: 12, 23, fig. 2-5h-j.

Material. RUMF-ZC-01273, 1 male (TL $18 \mathrm{~mm}$ ), Ara Beach, 26²18'58.9" N, 126 $46^{\prime} 26.0^{\prime \prime} \mathrm{E}$, intertidal stn 01, 16 Nov 2009; RUMF-ZC-01270, 1 female (TL 37 mm), Shinri Beach, 26²1'13.4" N, 126²4'59.6" E, intertidal stn 3, 18 Nov 2009; RUMF-ZC-01271, 2 males (TL 21-24 mm), 4 females (TL 17-27 mm), Ishidatami, Oh-jima Islet, $26^{\circ} 20^{\prime} 09.6^{\prime \prime} \mathrm{N}, 126^{\circ} 49^{\prime} 29.2^{\prime \prime} \mathrm{E}$, intertidal stn 5, 18-19 Nov 2009; AM P87566, 1 female (TL $25 \mathrm{~mm}$ ), Ishidatami, Oh-jima Islet, 26²0'09.6" N, 126²9'29.2" E, intertidal stn 5, 18-19 Nov 2009.

Remarks. Gonodactylellus viridis as currently understood represents a species complex, but the present specimens represent G. viridis sensu stricto. Moosa (1989) first recorded G. viridis from the Ryukyus.

Distribution. Andaman Sea and northwestern Australia eastwards to Taiwan and Japan; intertidal to shallow subtidal.

\section{Gonodactyloideus cracens Manning, 1984*\#}

(Fig. 4A)

Gonodactyloideus cracens Manning, 1984: 83-86, fig. 1 [type locality: Northwest Shelf, Western Australia, 1950'S, $115^{\circ} 34$ 'E]. — Moosa 1986: 379, fig. 3. — Ahyong 2001: 65, fig. 32; 2004: 3.

Material. RUMF-ZC-01276, 1 juvenile female (TL $13 \mathrm{~mm}$ ), $26^{\circ} 16.600-16.399^{\prime} \mathrm{N}, 1^{\circ} 6^{\circ} 53.336-53.083^{\prime} \mathrm{E}$, 157-166 m, trawl 26, 12 Nov 2009; RUMF-ZC-01254, 1 female (TL $38 \mathrm{~mm}$ ), 26 23.831-23.590`N, 126²5.685-45.212`E, 95.5-123 m, blocks, rubble, fish, decapods, cnidarians, trawl 70, 19 Nov 2009.

Remarks. The juvenile female differs from the adult in having shorter, less pronounced accessory median carinae on the telson and a posterior spine only on the median carina. The small posterior spines on the accessory median and anterior submedian carinae of the telson characteristic of adult G. cracens are incipient in the juvenile. The eyes of the juvenile are slightly compressed dorsoventrally, approaching the adult condition.

Distribution. Northwestern Australia, the Philippines and now from Japan; 80-166 m.

\section{Gonodactylus childi Manning, 1971\#}

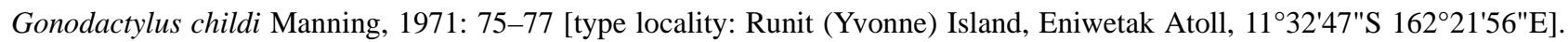
- Ahyong 2001: 67, fig. 33. — Osawa et al. 2004: 5-6, fig. 3A-D. - Hamano 2005: 12, 23, fig. 2-5k-m.

Gonodactylus chiragra. — Fukuda 1908: 510 (part); 1910: 141 (part); 1913: 72 (part). — Komai 1927: 338 [part] [Not G. chiragra (Fabricius, 1781)].

Not Gonodactylus childi Manning, 1971: fig. 1 [paratypes = Gonodactylellus incipiens (Lanchester, 1903)].

Material. RUMF-ZC-01275, 1 female (TL 26 mm), Ishidatami, Oh-jima Islet, 26²0'09.6" N, 126 49'29.2" E, intertidal stn 5, 18-19 Nov 2009.

Remarks. Gonodactylus childi was reported from the Ogasawara Islands (Chichi-jima) and Izu Islands (Miyake-jima or Nii-jima) by Osawa et al. (2004), so the present record is the first for the Ryukyus.

Distribution. Australia to Indonesia, Taiwan, Japan, Enewetak Atoll and French Polynesia; intertidal to shallow subtidal (Ahyong et al. 2008). 


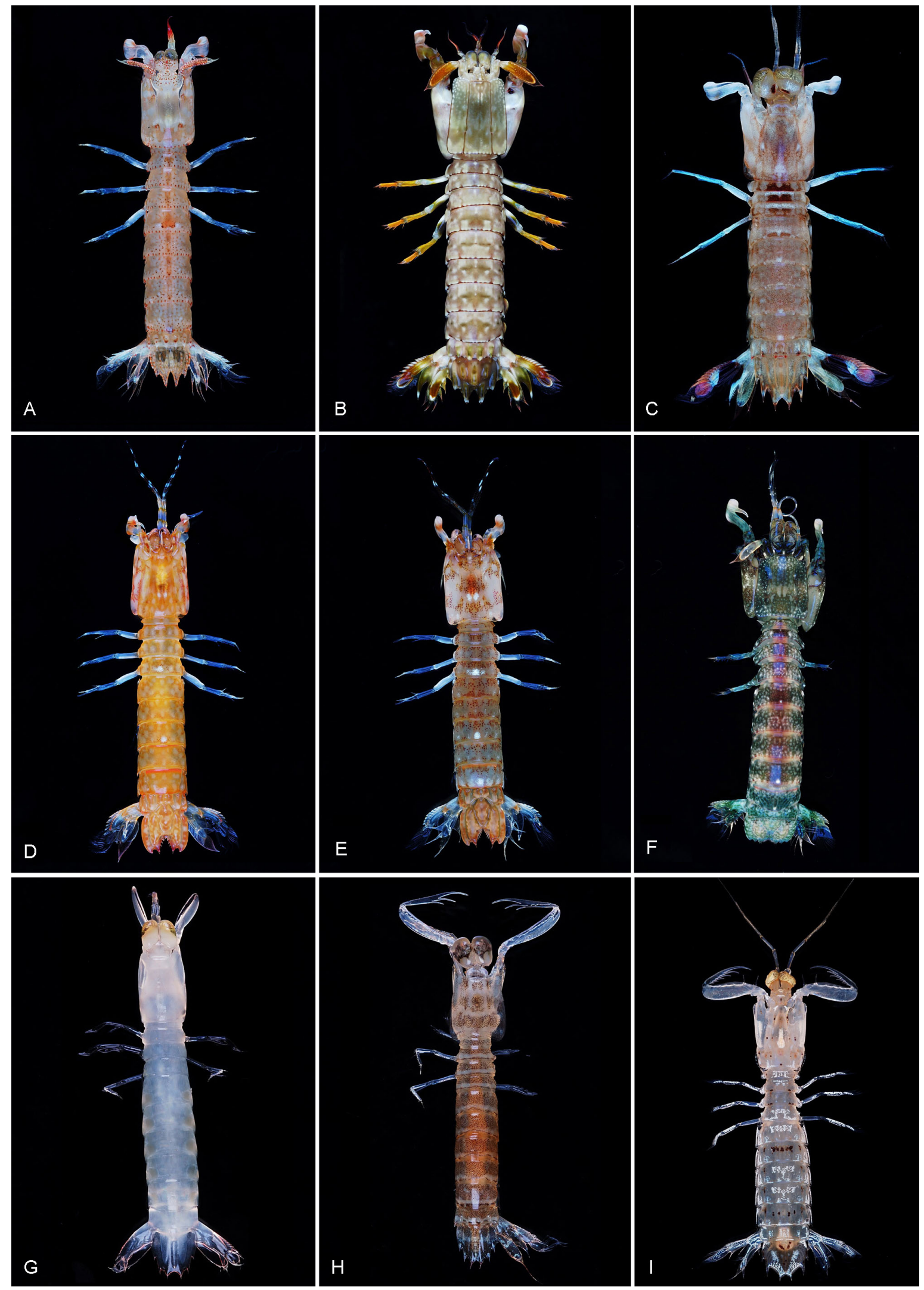

FIGURE 4. A, Gonodactyloideus cracens Manning, 1984, female TL 38 mm (RUMF-ZC-01254); B, Gonodactylus chiragra, male TL 64 mm (RUMF-ZC-01274); C, Odontodactylus hansenii Pocock, 1893, female TL 22 mm (RUMF-ZC-01279); D-E, Chorisquilla pococki Pocock, 1975, female TL 29 mm (RUMF-ZC-01277), male TL $21 \mathrm{~mm}$ (AM P87568); F, Haptosquilla glyptocercus (Wood-Mason, 1875), female TL 27 mm (RUMF-ZC-01278); G, Pseudosquilla ciliata (Fabricius, 1787), female postlarva TL $20 \mathrm{~mm}$ (AM P87570); H, Pseudosquillana richeri (Moosa, 1991), female TL $15 \mathrm{~mm}$ (RUMF-ZC-01280); I, Alima neptuni (Linnaeus, 1768), female TL 26 mm (RUMF-ZC-01285). 


\title{
Gonodactylus chiragra (Fabricius, 1781)
}

(Fig. 4B)

Squilla chiragra Fabricius, 1781: 515 [type locality: restricted to Ambon, Indonesia, $3^{\circ} 43^{\prime} \mathrm{S} 128^{\circ} 12^{\prime} \mathrm{E}$, by neotype selection (Manning 1981: 217)].

Gonodactylus chiragra. — Fukuda 1908: 510 (part), pl. 3, fig. 1; 1910: 141 (part); 1913: 72 (part). — Komai 1927: 338-339 (part). - Ahyong 2001: 67-70, fig. 34. Osawa et al. 2004: 5. — Hamano 2005: 12, 24, fig. 2-5n-p. — Ahyong $2007: 334$.

Material. RUMF-ZC-01274, 1 male (TL 64 mm), Ohara, 26²0'57.8" N, 126²3'33.9" E, intertidal stn 4, 18 Nov 2009; AM P87567, 1 male (TL 27 mm), Ishidatami, Oh-jima Islet, 26²0'09.6" N, 126²9'29.2" E, intertidal stn 5, 18-19 Nov 2009.

Remarks. Gonodactylus chiragra was first reported from the Ryukyus by Fukuda (1908).

Distribution. Western Indian Ocean to Australia, Indonesia, Vietnam, the Philippines, New Caledonia, Taiwan, Japan and French Polynesia; intertidal to shallow subtidal.

\section{ODONTODACTYLIDAE Manning, 1980}

\author{
Odontodactylus hansenii (Pocock, 1893)*\# \\ (Fig. 4C)
}

Gonodactylus Hansenii Pocock, 1893: 477, pl. 20b [type locality: Macclesfield Bank, South China Sea]. Odontodactylus hansenii. — Ahyong 2001: 78-79; 2002b: 829; 2004: 6-7; 2007: 334.

Material. RUMF-ZC-01279, 1 female (TL 22 mm), 26²3.090-22.966`N, $126^{\circ} 47.832-47.937^{`} \mathrm{E}, 82.0-81.3 \mathrm{~m}$, rubble, trawl 7, 10 Nov 2009.

Remarks. The specimen agrees well with Ahyong (2001). The proximal segment of the uropodal exopod is mostly black, and is longer than distal segment; abdominal somites 3-5 each have a posterolateral spine.

Distribution. Macclesfield Bank (South China Sea), the Philippines, New Caledonia, Hawaii, and now from Japanese waters; 81-439 m.

\section{PROTOSQUILLIDAE Manning, 1980}

\section{Chorisquilla pococki Manning, 1975\#}

(Fig. 4D-E)

Gonodactylus excavatus. — Odhner 1923: 15 [not G. excavatus Miers, 1880].

Chorisquilla pococki Manning, 1975: 256-258, fig. 1b, 2 [type locality: Macclesfield Bank, South China Sea]. - Ahyong 2001: 91. - Hamano 2005: 13, 29-30, fig. 2-7a-b. - Ahyong 2007: 334.

Chorisquilla excavata. — Moosa 1986: 383-384, fig. 4; 1991: 163 [not C. excavata (Miers, 1880)].

Material. RUMF-ZC-01277, 2 females (TL 10, 45 mm), 26¹9.907-20.056` N , 126 ${ }^{\circ} 43.191-42.622^{\prime} \mathrm{E}, 67.5-76 \mathrm{~m}$, dead coral blocks, rubble, trawl 45, 16 Nov 2009; AM P87568, 1 male (TL 21 mm), 26¹9.449-19.478`N, 12645.748-45.800`E, 8.9-9.3 m, dead coral branches, rubble, dredge 51, 16 Nov 2009.

Remarks. The specimens agree well with published accounts (Manning 1975; Moosa 1986). Odhner (1923) first reported C. pococki from Japanese waters (Ogasawara Islands), and the present specimens are the first records for the Ryukyus.

Distribution. South China Sea including the Philippines to Japan; 8.9-76 m. 


\section{Haptosquilla glyptocercus (Wood-Mason, 1875)}

(Fig. 4F)

Gonodactylus glyptocercus Wood-Mason, 1875: 232 [type locality: Nicobar Is, Andaman Sea, $\left.8^{\circ} 00^{\prime} \mathrm{N} 93^{\circ} 30^{\prime} \mathrm{E}\right] .-\mathrm{Kemp}$, 1913: 11, 186-187. - Komai 1927: 341-342.

Protosquilla cerebralis Brooks, 1886: 22, 72, pl. 14: figs. 2, 3, pl. 16: figs. 2, 3 [type locality: Levuka, Fiji, 17²4'S $178^{\circ} 50^{\prime} \mathrm{E}$ ]. — Fukuda 1908: 507, pl. 1, fig. 1; 1910: 139; 1913: 72.

Haptosquilla glyptocercus.-Manning, 1995: 21, 102-104, pl. 18, figs. 9 m, 43b, 52, 53. - Ahyong 2001: 104-105, fig. 50. Osawa et al. 2004: 7-8, fig. 3E. - Hamano 2005: 13, 33, fig. 2-7j-1. — Ahyong 2007: 334.

Material. RUMF-ZC-01278, 1 female (TL 27 mm), Ishidatami, Oh-jima Islet, 26²0'09.6" N, 126²9'29.2" E, intertidal stn 5, 18-19 Nov 2009; AM P87569, 1 female (TL 26 mm), same locality.

Remarks. Haptosquilla glyptocercus was first recorded from the Ryukyus by Fukuda (1908).

Distribution. Andaman Sea to Australia, New Caledonia, the Philippines, Japan, Vietnam, Fiji, Enewetak Atoll and Guam; intertidal to shallow subtidal (Ahyong 2001).

\section{PSEUDOSQUILLIDAE Manning, 1977}

\section{Pseudosquilla ciliata (Fabricius, 1787)\#}

(Fig. 4G)

Squilla ciliata Fabricius, 1787: 333 [type locality: Exmouth Gulf, Western Australia, by neotype selection (Ahyong 2001)]. Squilla stylifera Lamarck, 1818: 189 [type locality: unknown].

Squilla quadrispinosa Eydoux \& Souleyet, 1842: 362, pl. 5, fig. 1 [type locality Sandwich Islands (= Hawaiian Islands)].

Pseudosquilla ciliata var. occidentalis Borradaile, 1900: 398, 402 [type locality: West Indies].

Pseudosquilla ciliata. — Fukuda 1909: 57, pl. 2, fig. 4; 1910: 145; 1913: 72. — Kemp, 1913: 10, 96-100. — Komai 1927: 323. — Ahyong 2001: 112-115, fig. 55. — Osawa et al. 2004: 8. — Hamano 2005: 13, 36, fig. 2-8a-d.

Material. AM P87570, 1 female postlarva (TL $20 \mathrm{~mm}$ ), $26^{\circ} 19.714-19.579^{\prime} \mathrm{N}, 126^{\circ} 45.649-45.707^{`} \mathrm{E}, 17.9-42.5$ $\mathrm{m}$, rubble, dredge 44, 14 Nov 2009.

Remarks. The specimen represents the first record of $P$. ciliata from the Ryukyus and agrees well with the description of the postlarva by Manning (1977).

Distribution. Widely distributed throughout the tropical Indo-West Pacific, eastern and western Atlantic.

\section{Pseudosquillana richeri (Moosa, 1991)}

(Fig. 4H)

Pseudosquilla richeri Moosa, 1991: 175-176, fig. 5 [type locality: New Caledonia, $18^{\circ} 27.2^{\prime} \mathrm{S} 163^{\circ} 02.3^{\prime} \mathrm{E}$ ].

Pseudosquillana richeri. — Ahyong et al. 2000: 306-310, figs. 2, 3. — Ahyong 2001: 115, fig. 56; $2007: 334$.

Material. RUMF-ZC-01280, 1 female (TL $15 \mathrm{~mm}$ ), $26^{\circ} 18.330-18.351^{`} \mathrm{~N}, 126^{\circ} 49.730-49.734^{`} \mathrm{E}, 27-28 \mathrm{~m}, 27-28$ $\mathrm{m}$, trawl 15, 11 Nov 2009; RUMF-ZC-01281, 1 juvenile male (TL $16 \mathrm{~mm}$ ), Nanguchi, $26^{\circ} 18.536^{\prime} \mathrm{N}$, $126^{\circ} 50.402$ E,$<25 \mathrm{~m}$, dead coral rubble, reef-end, dive 8, 11 Nov 2009.

Remarks. The specimens have the banded colour pattern characteristic of juvenile $P$. richeri. Ahyong et al. (2000) first recorded $P$. richeri from the Ryukyus (Amami-oshima Island).

Distribution. Red Sea to Australia, New Caledonia, the Philippines, Oceania, French Polynesia and from Japan; intertidal to at least $15 \mathrm{~m}$ (Ahyong 2001).

LYSIOSQUILLOIDEA Giesbrecht, 1910

NANNOSQUILLIDAE Manning, 1980 


\section{Acanthosquilla multifasciata (Wood-Mason, 1895)\#}

Lysiosquilla multifasciata Wood-Mason, 1895: 1-2, figs. 22-24 [type locality: Bombay, India]. — Komai 1927: $332-333$.

Lysiosquilla Valdiviensis Jurich, 1904: 372, pl. 26: fig. 2 [type locality unknown].

Lysiosquilla biminiensis var. pacificus Borradaile, 1900: 395, 398, 403 [type locality: Blanche Bay, New Britain, 4¹6'S $\left.152^{\circ} 13 ' \mathrm{E}\right]$.

Acanthosquilla multifasciata.— Manning 1995: 143-147, pls. 25, 26, figs. 78b, 80b, 81a,b,e,f, 82a,b, 83-86. - Ahyong 2001: 144-146, fig. 71. — Hamano 2005: 13, 43, fig. 2-11e-j. — Ahyong 2007: 334.

Material. RUMF-ZC-01282, 1 female (broken; CL $8.7 \mathrm{~mm}$ ), 26¹9.838-19.725№, $126^{\circ} 52.013-51.670^{\prime} \mathrm{E}$, 10.4-13.6 m, dredge 65, 18 Nov 2009.

Remarks. The specimen, the first record of A. multifasciata from the Ryukyus, lacks the body posterior to abdominal somite 1 . The dactyli of both raptorial claws are armed with 6 teeth.

Distribution. Red Sea to Vietnam, Australia, Japan and Hawaii; intertidal to 73 m (Ahyong 2001).

\section{Pullosquilla thomassini Manning, 1978\#}

Lysiosquilla n. sp.—Odhner 1923: 7.

Pullosquilla thomassini Manning, 1978: 20-21, fig. 9 [type locality: Grand Recif, Tuléar, Madagascar]. — Ahyong 2001: 168, fig. 84.

Material. RUMF-ZC-01283, 1 female (TL $11 \mathrm{~mm}$ ), 26 $19.054-18.958^{`} \mathrm{~N}, 1^{\circ} 6^{\circ} 48.702-48.724^{\prime} \mathrm{E}, 5.6-13.1 \mathrm{~m}$, mud, dredge 69, 18 Nov 2009; AM P87571, 1 male (TL 12 mm), 1 female (TL 12 mm), Koukou-mae (in front of high school), $26^{\circ} 19.885^{\prime} \mathrm{N}, 126^{\circ} 45.616^{\prime} \mathrm{E}$, <4 m, mud, dead coral rubble, yabby pump, dive 16, 14 Nov 2009; RUMF-ZC-01284, 1 male (TL $10 \mathrm{~mm}$ ), 1 female (TL $10 \mathrm{~mm}$ ), 26¹9.442-19.378` N, 126 $49.211-49.1^{\circ} 8^{`} \mathrm{E}$, 4.7-9.5 m, dredge 55, 17 Nov 2009.

Remarks. Pullosquilla thomassini ranges widely in the Indo-West Pacific, including southern Japan (Ogasawara Islands) (Ahyong 2001). The present specimens are the first records for the Ryukyu Islands. The armature of the false eave (16-20 spines) and dactyli of the raptorial claws (12-16 teeth) are within the documented range (Manning 1978; Ahyong 2001).

Distribution. Widespread throughout the Indo-West Pacific, from Madagascar and the Red Sea to Australia, southern Japan (Ogasawara and Ryukyu Islands) and French Polynesia; intertidal to 40 m (Ahyong 2001).

\section{SQUILLOIDEA Latreille, 1802}

\section{SQUILLIDAE Latreille, 1802}

\section{Alima neptuni (Linnaeus, 1768)*\#}

(Fig. 4I)

Cancer neptuni Linnaeus, 1768: 226 [type locality: Bimini Harbor, Bimini Islands, Straits of Florida, by neotype selection (Holthuis 2000)]. - Holthuis 2000: 17-18.

Alima hyalina Leach in Tuckey, 1817: unnumbered plate in appendix IV to Tuckey [Porto Praya, Cape Verde Islands].

Alima gracilis H. Milne Edwards, 1837: 509 [type locality: Bimini Harbor, Bimini Islands, Straits of Florida, by present neotype selection].

Alima angusta Dana, 1852: 631 [type locality: Bimini Harbor, Bimini Islands, Straits of Florida, by present neotype selection]. Squilla alba Bigelow, 1893: 103 [type locality: Bimini Harbor, Bimini Islands, Straits of Florida].

Alima gracillima Borradaile, 1907: 216, pl. 22, fig. 5 [type locality: Western Indian Ocean].

Alima neptuni. - Ahyong 2001: 188-189; 2002a: 362.

Material. RUMF-ZC-01285, 1 female (TL 26 mm), Suna Point, 26¹8`N, 12650.244`E, < 9 m, sand, rubble, dive 9, 11 Nov 2009.

Remarks. The single specimen of A. neptuni collected here represents the first record of the species from Japanese waters and agrees well with published accounts (Manning 1977; Ahyong 2001, 2002a). The abdominal 
carinae are spined as follows: submedian 6, intermediate 5-6, lateral 5-6, marginal 3-5.

Confusion has long surrounded the identities of A. neptuni and its suggested synonyms, A. alba (Bigelow, 1893) [type locality: Bimini Islands], A. angusta Dana, 1852 [original type locality: eastern Atlantic Ocean, $02^{\circ} 30^{\prime} \mathrm{N}, 17^{\circ} 15^{\prime} \mathrm{W}$ ], A. gracillima Borradaile, 1907 [type locality: western Indian Ocean]; A. gracilis H. Milne Edwards, 1837 [original type locality: Indian Ocean]; A. hyalina Leach, 1817 [type locality: Cape Verde Islands] (Manning 1962; Schotte \& Manning 1993; Holthuis 2000). Apart from A. alba, all of these names were erected based on larval forms. Holthuis (2000) took the first formal step towards stabilizing these names by fixing a neotype for A. neptuni using the lectotype of A. alba (USNM 18495, female, TL $41 \mathrm{~mm}$ ) making the two nomina objective synonyms. The identities of Alima angusta and A. gracilis, however, remained ambiguous, both too being originally based on larvae, for which the type material is now lost. To stabilize the identities of Dana's and Milne Edwards' species, the neotype of $A$. neptuni (= lectotype of $A$. alba) is selected as the simultaneous neotype of both A. angusta and A. gracilis. Thus, A. angusta, A. alba and A. gracilis are each objective synonyms of A. neptuni, each having its name anchored to the same specimen and same type locality, the Bimini Islands.

As suggested by Manning (1969), A. gracillima, described from larvae collected in the western Indian Ocean, probably represents an early larva of A. neptuni (as A. hyalina).

Distribution. All tropical oceans except the eastern Pacific. In the Indo-West Pacific, ranging from the western Indian Ocean to Hawaii and French Polynesia.

\section{Cloridina chlorida (Brooks, 1886)*\#}

Squilla chlorida Brooks, 1886: 21, 40, pl. 2, figs. 1-5 [type locality: Amboina, Indonesia, $3^{\circ} 43^{\prime} \mathrm{S} 128^{\circ} 12^{\prime} \mathrm{E}, 27 \mathrm{~m}$ ]. Cloridina chlorida. — Manning 1995: 24, 192. — Ahyong 2001: 232-233, fig. 113; 2007: 335.

Material. RUMF-ZC-01286, 1 juvenile male (TL $17 \mathrm{~mm}$ ), 26²19.581-19.409`N, 126 $44.271-44.607^{`} \mathrm{E}, 60-94 \mathrm{~m}$, sand, dredge 39, 14 Nov 2009.

Remarks. The specimen is a juvenile, having a partially modified pleopod 1 endopod and no armed carinae on abdominal somites 1-5. The dorsal processes of the antennular somite are acutely angular rather than spinular as in adults, and the postanal carina is absent as is usually the case in adults. As in adults, the raptorial claws have five teeth on the dactylus and thoracic somite 5 has a spiniform lateral spine and a small ventral spine. The dorsally mottled colour pattern is similar to that of adults.

Distribution. Madagascar to Australia, Indonesia, Vietnam, New Caledonia and now from Japan; 10-108 m (Ahyong 2001).

\section{Leptosquilla schmeltzii (H. Milne Edwards, 1837)*\#}

Squilla schmeltzii H. Milne Edwards, 1837: 11, pl. 2, fig. 7 [type locality: Upolu, Samoa]. Leptosquilla schmeltzii. — Moosa 1991: 207-208. — Ahyong 2007: 335.

Material. RUMF-ZC-01287, 2 females (TL $14 \mathrm{~mm} ; 1$ broken, CL $2.9 \mathrm{~mm}$ ), 26 ${ }^{\circ} 19.553-19.463^{\prime} \mathrm{N}$, 126 49.510-49.491`E, 9.1-13.3 m, sand, dredge 58, 17 Nov 2011.

Remarks. The specimens are in poor condition and both lack the raptorial claws.

Distribution. East Africa and the Red Sea to Indonesia, New Caledonia, Samoa and now from Japan; 11-45 m (Moosa 1991).

\section{Parvisquilla multituberculata (Borradaille, 1898)*\#}

(Fig. 5)

Squilla multituberculata Borradaille, 1898: 38, pl. 6, figs 7, 7a-c [type locality: Sandal Bay, Lifou]. Parvisquilla xishaensis Liu, 1975: 183-184, 196, pl. 1, figs 1-6 [type locality: Xisha Islands, China]. Parvisquilla multituberculata. — Manning 1978: 16-18, fig. 8. — Ahyong \& Erdmann 2003: 346-347. 

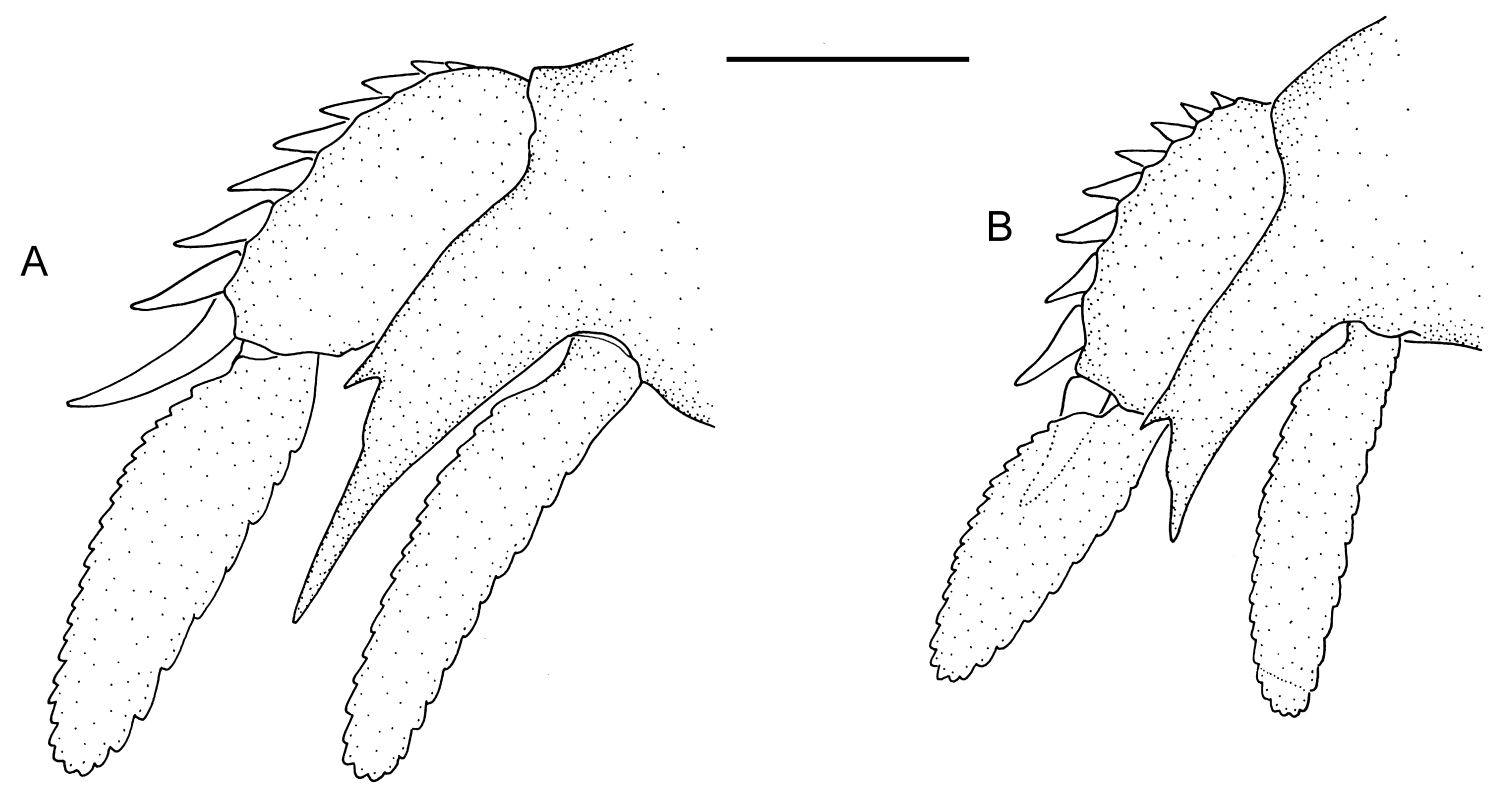

FIGURE 5. Parvisquilla multituberculata (Borradaile, 1898), right uropod, ventral view (RUMF-ZC-1288). A, male, TL 11 $\mathrm{mm}$. B, female, TL $9 \mathrm{~mm}$. Scale $=0.5 \mathrm{~mm}$.

Material. RUMF-ZC-01288, 1 male (TL $11 \mathrm{~mm}$ ), 1 female (TL $9 \mathrm{~mm}$ ), 26¹9.907-20.056` $\mathrm{N}$, 12643.191-42.622`E, 67.5-76 m, dead coral blocks, rubble, trawl 45, 16 Nov 2009.

Remarks. As reported by Ahyong \& Erdmann (2003) for P. multituberculata, sexual dimorphism in the present specimens is evident in the length of the primary spine of the uropodal protopod, being proportionally longer in males than in females (Fig. 2).

Distribution. Widely distributed in the Indo-West Pacific, from the western Indian Ocean to French Polynesia; a new record for Japanese waters.

\section{CHECKLIST OF STOMATOPODA FROM JAPAN}

Hamano (2004) listed 56 species of Stomatopoda from Japan, but inadvertently omitted Pseudosquillana richeri, recorded from the the Ryukyus by Ahyong et al. (2000). Subsequently, Ahyong et al. (2008) removed Harpiosquilla japonica from the synonymy of $H$. harpax, bringing the total to 58 species. The results of the present study raise the number of stomatopod species recorded from Japan to 68. Species studied herein are in bold. New records for Japan are indicated (*). New records for the Ryukyu Islands are indicated (\#)

BATHYSQUILLOIDEA Manning, 1967

Bathysquillidae Manning, 1963

Bathysquilla crassispinosa (Fukuda, 1909)

ERYTHROSQUILLOIDEA Manning \& Bruce, 1984

Erythrosquillidae Manning \& Bruce, 1984

Erythrosquilla hamano Ahyong, 2001

GONODACTYLOIDEA Giesbrecht, 1910

Gonodactylidae Giesbrecht, 1910

Gonodactylaceus glabrous (Brooks, 1886)*\#

Gonodactylaceus falcatus (Forskål, 1775)

Gonodactylellus annularis Erdmann \& Manning, 1998*\# 
Gonodactylellus kume sp. nov. *\#

Gonodactylellus rubriguttatus Erdmann \& Manning, 1998*\#

Gonodactylellus snidvongsi (Naiyanetr, 1987)

Gonodactylellus viridis (Serène, 1954)

Gonodactyloideus cracens Manning, 1984*\#

Gonodactylus childi Manning, 1971\#

Gonodactylus chiragra (Fabricius, 1781)

Gonodactylus platysoma Wood-Mason, 1895

Gonodactylus smithii Pocock, 1893

Odontodactylidae Manning, 1980

Odontodactylus brevirostris (Miers, 1884)

Odontodactylus hansenii (Pocock, 1893) *\#

Odontodactylus japonicus (De Haan, 1844)

Odontodactylus scyllarus (Linnaeus, 1758)

Protosquillidae Manning, 1980

Chorisquilla pococki Manning, 1975\#

Chorisquilla tuberculata (Borradaile, 1907)

Chorisquilla sp.

Echinosquilla guerini (White, 1861)

Haptosquilla glyptocercus (Wood-Mason, 1875)

Haptosquilla pulchella (Miers, 1880)

Haptosquilla tanensis (Fukuda, 1911)

Pseudosquillidae Manning, 1977

Pseudosquilla ciliata (Fabricius, 1787)\#

Pseudosquillana richeri (Moosa, 1991)

Raoulserenea hieroglyphica (Manning, 1972)

Raoulserenea oxyrhyncha (Borradaile, 1898)

Takuidae Manning, 1995

Mesacturus furcicaudatus (Miers, 1880)

Taku spinosocarinatus (Fukuda, 1909)

LYSIOSQUILLOIDEA Giesbrecht, 1910

Lysiosquillidae Giesbrecht, 1910

Lysiosquilla sulcirostris Kemp, 1911

Lysiosquillina maculata (Fabricius, 1793)

Nannosquillidae Manning, 1980

Acanthosquilla derijardi Manning, 1970

Acanthosquilla multifasciata (Wood-Mason, 1895)\#

Bigelowina phalangium (Fabricius, 1798)

Pullosquilla thomassini Manning, 1978\#

Tetrasquillidae Manning \& Camp, 1993

Acaenosquilla latifrons (De Haan, 1844)

Allosquilla varicosa (Komai \& Tung, 1930)

Tetrasquilla mccullochae (Schmitt, 1940)

PARASQUILLOIDEA Manning, 1995

Parasquillidae Manning, 1995

Faughnia formosae Manning \& Chan, 1997

Faughnia haani (Holthuis, 1959)

Faughnia serenei Moosa, 1982

Pseudosquillopsis dofleini (Balss, 1910)

SQUILLOIDEA Latreille, 1802

Squillidae Latreille, 1802

Alima hieroglyphica (Kemp, 1911) 


\author{
Alima neptuni (Linnaeus, 1768) *\# \\ Anchisquilla fasciata (De Haan, 1844) \\ Busquilla quadraticauda (Fukuda, 1911) \\ Carinosquilla multicarinata (White, 1849) \\ Clorida japonica Manning, 1978 \\ Cloridina chlorida (Brooks, 1886) *\# \\ Cloridopsis scorpio (Latreille, 1828) \\ Erugosquilla woodmasoni (Kemp, 1911) \\ Harpiosquilla annandalei (Kemp, 1911) \\ Harpiosquilla harpax (De Haan, 1844) \\ Harpiosquilla japonica Manning, 1969 \\ Harpiosquilla melanoura Manning, 1968 \\ Kempella mikado (Kemp \& Chopra, 1921) \\ Lenisquilla lata (Brooks, 1886) \\ Leptosquilla schmeltzii (H. Milne Edwards, 1837)*\# \\ Levisquilla inermis (Manning, 1965) \\ Lophosquilla costata (De Haan, 1844) \\ Oratosquilla kempi (Schmitt, 1931) \\ Oratosquilla oratoria (De Haan, 1844) \\ Oratosquillina perpensa (Kemp, 1911) \\ Parvisquilla multituberculata (Borradaile, 1898)*\# \\ Quollastria gonypetes (Kemp, 1911) \\ Quollastria imperialis (Manning, 1965) \\ Squilloides leptosquilla (Brooks, 1886)
}

\title{
Acknowledgements
}

The KUMEJIMA 2009 Expedition was a jointly organized by the Transdisciplinary Research Organization for Subtropical and Island Studies of the University of the Ryukyus (TRO-SIS), the Center for Marine Bioscience \& Biotechnology of the National Taiwan Ocean University (CMBB), the Raffles Museum of Biodiversity Research of the National University of Singapore (RMBR), and the Biodiversity Research Center of the Academia Sinica (BRCAS). The expedition operated under a permit from the Okinawa Prefectural Governor and the Kumejima Fisheries Cooperative granted to the expedition leader, T. Naruse of the University of the Ryukyus. Colour photographs of specimens examined were taken by T.-Y. Chan of the National Taiwan Ocean University. Thanks go to Karen Reed (USNM) and Andrew Hosie (WAM) for loan of additional specimens.

\section{References}

Ahyong, S.T. (2001) Revision of the Australian Stomatopod Crustacea. Records of the Australian Museum, Supplement 26, $1-326$.

Ahyong, S.T. (2002a) Stomatopod Crustacea from the Marquesas Islands: results of MUSORSTOM 9. Zoosystema, 24, 347-372.

Ahyong, S.T. (2002b) A new species and new records of Stomatopoda from Hawaii. Crustaceana, 75, 827-840.

Ahyong, S.T. (2004) New species and new records of stomatopod Crustacea from the Philippines. Zootaxa, 793, 1-28.

Ahyong, S.T. (2007) Shallow water Stomatopoda of New Caledonia (0-100 m). In: Payri, C.E. \& Richer de Forges, B. (Eds), Compendium of Marine Species from New Caledonia. Documents Scientifiques et Techniques, Vol. II7, 333-335. IRD Noumea, Noumea.

Ahyong, S.T. (2008) Stomatopod Crustacea from the Dampier Archipelago, Western Australia. Records of the Western Australian Museum, Supplement 73, 41-55.

Ahyong, S.T. (2012) The Marine Fauna of New Zealand: Mantis Shrimps (Crustacea: Stomatopoda). NIWA Biodiversity Memoir, 125, 1-112.

Ahyong, S.T. \& Erdmann, M.V. (2003) The stomatopod Crustacea of Guam. Micronesica, 35-36, 315-352.

Ahyong, S.T. \& Erdmann, M.V. (2007) Two new species of Gonodactylellus from Indonesia. Raffles Bulletin of Zoology, 55, 
89-95.

Ahyong, S.T., Manning, R.B. \& Reed, K. (2000) Revision of Pseudosquillana Cappola \& Manning, 1995 (Crustacea: Stomatopoda: Pseudosquillidae). Raffles Bulletin of Zoology, 48, 301-311.

Ahyong, S.T. \& Naiyanetr, P. (2002) Stomatopod Crustaceans from Phuket and the Andaman Sea. Phuket Marine Biological Centre Special Publication, 23, 281-312.

Ahyong, S.T. \& Norrington, S.F. (1997) Stomatopod Crustacea in the Macleay Museum, University of Sydney. Proceedings of the Linnean Society of New South Wales, 118, 97-110.

Ahyong, S.T., Chan, T.-Y. \& Liao, Y.-C. (2008) A Catalog of the Mantis Shrimps (Stomatopoda) of Taiwan. National Science Council, Taiwan, R.O.C., Taipei, vii + 191 pp.

Balss, H. (1910) Ostasiatische Stomatopoden. Beiträge zur Naturgeschichte Ostasiens. Herausgegeben von Dr. F. Doflein. Abhandlungen der Wissenschaften, Mathematisch-Naturwissenschaftliche Klasse, Munich, supplement 2, 2, 1-11.

Bigelow, R.P. (1893) The Stomatopoda of Bimini. Johns Hopkins University Circulars, 12(106), 102-103.

Borradaile, L.A. (1898) On some Crustaceans from the South Pacific-Part I: Stomatopoda. Proceedings of the Zoological Society of London, 1898, 32-38.

Borradaile, L.A. (1900) On the Stomatopoda and Macrura brought by Dr Willey from the South Seas. In: Willey, A. (Ed.), Zoological Results based on the material from New Britain, New Guinea, Loyalty Islands and elsewhere, collected during the years 1895, 1896, and 1897, 4, 395-428. Cambridge University Press, Cambridge.

Borradaile, L.A. (1907) Stomatopoda from the western Indian Ocean. The Percy Sladen Trust Expedition to the Indian Ocean in 1905, under the leadership of J. Stanley Gardiner. Transactions of the Linnean Society of London (2, Zoology), 12, 209-216, pl. 22.

Brooks, W.K. (1886) Report on the Stomatopoda collected by H.M.S. Challenger during the years 1873-76. The Voyage of the H.M.S. Challenger, Zoology, 16, 1-116, pl. 1-16.

Dana, J.D. (1852-1855) Crustacea, Part 1. United States Exploring Expedition during the years 1838, 1839, 1840, 1841, 1842, under the command of Charles Wilkes, U.S.N., 13, 1-685 (1852). Atlas, 1-27, pls. 1-96 (1855). C. Sherman, Philadelphia.

Erdmann, M.V. \& Manning, R.B. (1998) Preliminary descriptions of nine new stomatopod crustaceans from coral reef habitats in Indonesia and Australia. Raffles Bulletin of Zoology, 46, 615-626.

Eydoux, F. \& Souleyet, L.F.A. (1842). Crustacés. Voyage autour du Monde exécuté pendent les années 1836 et 1837 sur la Corvette La Bonite Commandée par M. Vaillant, Capitaine de Vaiseau, Zoologie, 1, 219-272. Arthus Bertrand, Paris.

Fabricius, J.C. (1781) Species Insectorum Exhibentes Eorum Differentias Specificas, Synonyma Auctorum, Loca Natalia, Metamorphosin Adiectis, Observationibus, Descriptionibus 1, vii + 552. Hamburgii et Kilonii.

Fabricius, J.C. (1787) Mantissa insectorum sistens eorum species nuper detectas: adjectis characteribus genericis, differentiis specificis, emendationibus, observationibus, 1, 1-348. Proft Hafniae.

Fabricius, J.C. (1793) Entomologia Systematica Emendata et Aucta. Secundum Classes, Ordines, Genera, Species. Adjectis Synonimis, Locis, Observationibus, Descriptionibus, 2, pp. vii + 519. Hafniae.

Fabricius, J.C. (1798) Supplementum Entomologiae Systematicae, pp. ii + 572. Hafniae.

Forskål, P. (1775) Descriptiones Animalium, Avium, Amphibiorum, Piscium, Insectorum, Vermium, pp. $19+$ xxxii +164 . Hauniae (Copenhagen).

Fukuda, T. (1908) Japanese Stomatopoda. Doubutsugaku Zasshi, 20, 505-512, pl. 1. (In Japanese).

Fukuda, T. (1909) Japanese Stomatopoda. Dobutsugaku Zasshi, 21, 54-62, 167-174, pl. 5 (In Japanese; published in English, 1910).

Fukuda, T. (1910) Report on Japanese Stomatopoda with descriptions of two new species. Annotationes Zoologicae Japonenses, 7, 139-152, pl. 4.

Fukuda, T. (1911) Supplement to Japanese Stomatopoda. Dobutsugaku Zasshi, 23, 173-175.

Fukuda, T. (1913) Two Japanese stomatopods, with list of stomatopods in the Japanese waters. Doubutsugaku Zasshi (Zoological Magazine), 25, 69-72. (In Japanese)

Giesbrecht, W. (1910) Stomatopoden, Erster Thezil. Fauna und Flora des Golfes von Neapel, 33, i-vii, 1-239, pl. 1-11.

Haan, W. de, (1833-1850) Crustacea. In: Fauna Japonica sive descriptio animalium, quae in itinere per Japoniam, jussu et auspiciis superiorum, qui summum in India Batavia Imperium tenent, suscepto, annis 1823-1830 collegit, notis observationibus et adumbrationibus, ed. Ph.F. von Siebold, pp. 243, illustravit. A. Arnz, Lugdunum Batavorum.

Hamano, T. (2005) Biology of stomatopod crustaceans and stock management of the Japanese mantis shrimp Oratosquilla oratoria. Japan Fisheries Resource Conservation Association, Tokyo, 208 pp. (In Japanese).Holthuis, L.B. (1959) Stomatopod Crustacea of Suriname. Studies on the Fauna of Suriname and other Guyanas, 10, 173-191.

Holthuis, L.B. (2000) Nomenclatural notes on eighteenth century Stomatopoda (Hoplocarida). Journal of Crustacean Biology, 20, 12-19.

Jurich, B. (1904) Die Stomatopoden der Deutsche Tiefsee-Expedition. Wissenschaftliche Ergebnisse der deutschen TiefseeExpedition auf dem Dampfer "Valdivia" 1898-1899, 7, 361-408, pls. 25-30.

Kemp, S. (1911) Preliminary descriptions of new species and varieties of Crustacea Stomatopoda in the Indian Museum. Records of the Indian Museum, 6, 93-100.

Kemp, S. (1913) An account of the Crustacea Stomatopoda of the Indo-Pacific region, based on the collection in the Indian Museum. Memoirs of the Indian Museum, 4, 1-217.

Kemp, S. \& Chopra, B. (1921) Notes on Stomatopoda. Records of the Indian Museum, 22, 297-311. 
Komai, T. (1927) Stomatopoda of Japan and adjacent localities. Memoirs of the College of Science, Kyoto Imperial University, series $B, 3,307-354$.

Komai, T. (1940) Gonodactylus furcicaudatus Miers, a remarkable stomatopod. Annotationes Zoologicae Japonenses, 19(1), 47-50.

Komai, T. \& Tung, Y.M. (1930) Report on the Stomatopoda Collected by the surveying ships of the Imperial Fisheries Experimental Station on the continental shelf bordering Japan. Annotationes Zoologicae Japonenses, 13(1), 13-19.

Lamarck, J.B.P.A. (1818). Histoire naturelle des animaux sans vertèbres présentant les caractères généraux et particulier de ces animaux, leur distribution, leur classes, leurs familles, leurs genres, et la citation des principales espèces qui s'y rapportent; précédée d'une introduction offrant la détermination des caractères essentiels, de l'animal, sa distinction du végétal et des autres corps naturels, enfin, l'exposition des principes fondamentaux de la zoologie, 5, 1-612. Déterville, Paris.

Lanchester, W.F. (1903) Stomatopoda, with an account of the varieties of Gonodactylus chiragra. Marine Crustaceans VIII. In: Gardiner, J.S. (Ed.), The fauna and geography of the Maldive and Laccadive Archipelagoes: being the account of the work carried on and of the collections made by an expedition during the years 1899 and 1900, 1, 444-459.

Latreille, P.A. (1802) Histoire naturelle, générale et particulière, des Crustacés et des Insectes, 3, 1-467. F. Dufart, Paris.

Latreille, P.A. (1828) Squille, Squilla. Encyclopédie Méthodique.Entomologie ou Histoire naturelle des Crustacés, des Arachnides et des Insectes, 10, 467-475. Agasse, Paris.

Liu, J.Y. (1975) On a collection of stomatopod Crustacea from the Xisha Islands, Guangdong Province, China. Studia Marina Sinica, 10, 183-197, pl. 1.

Linnaeus, C. (1758) Systema Naturae per Regna Tria Naturae, Secundum Classes, Ordines, Genera, Species, cum Characteribus,Differentiis, Synonymis Locis. Edition 10, vol. 1, pp. iii + 824. Holmiae.

Linnaeus, C. (1768) Systema naturae per regna tria naturae, secundum classes, ordines, genera, species, cum characteribus, differentiis, synonymis locis, 3, 1-236. Stockholm, 12th ed.

Leach, W. E. (1817-1818) A general notice of the animals taken by Mr John Cranch, during the expedition to explore the source of the River Zaire. In: Tuckey, J. K. (Ed.), Narrative of an expedition to explore the River Zaire, usually called the Congo, in South Africa, in 1816, under the Direction of Captain J. K. Tuckey, R. N., to which is added the journal of Professor Smith, some general observations on the country and its Inhabitants, and an appendix, containing the natural history of that part of the Kingdom of Congo through which the Zaire flows. Appendix 4, 407-419 (1818), 1 unnumbered plate (1817). John Murray, London.

Manning, R.B. (1962) Alima hyalina Leach, the pelagic larva of the stomatopod crustacean Squilla alba Bigelow. Bulletin of Marine Science of the Gulf and Caribbean, 12(3), 496-507.

Manning, R.B. (1963) Preliminary revision of the genera Pseudosquilla and Lysiosquilla with descriptions of six new genera. Bulletin of Marine Science of the Gulf and Caribbean, 13, 308-328.

Manning, R.B. (1965) Stomatopoda from the collection of His Majesty The Emperor of Japan. Crustaceana, 9, 249-262, pls. $11-12$.

Manning, R.B. (1967) Preliminary account of a new genus and a new family of Stomatopoda. Crustaceana, 13(2), 238-239.

Manning, R.B. (1968) Stomatopod Crustacea from Madagascar. Proceedings of the United States National Museum, $124,1-61$.

Manning, R.B. (1969) Stomatopod Crustacea of the Western Atlantic. Studies in Tropical Oceanography, 8, 1-380.

Manning, R.B. (1970). Some stomatopod crustaceans from Tuléar, Madagascar. Bulletin du Muséum national d'Histoire naturelle,Paris, series 2, 41(6), 1429-1441. (Dated 1969, published 1970).

Manning, R.B. (1971) Two new species of Gonodactylus (Crustacea, Stomatopoda), from Eniwetok Atoll, Pacific Ocean. Proceedings of the Biological Society of Washington, 84, 73-80.

Manning, R.B. (1972) Two new species of Pseudosquilla (Crustacea, Stomatopoda) from the Pacific Ocean. American Museum Novitates, 2484, 1-11.

Manning, R.B. (1975) Two new species of the Indo-West Pacific genus Chorisquilla (Crustacea, Stomatopoda), with notes on C. excavata (Miers). Proceedings of the Biological Society of Washington, 88, 253-262.

Manning, R.B. (1977) A monograph of the West African stomatopod Crustacea. Atlantide Report, 12, $25-181$.

Manning, R.B. (1978) New and rare stomatopod Crustacea from the Indo-West Pacific region. Smithsonian Contributions to Zoology, 264, 1-36.

Manning, R.B. (1980) The superfamilies, families, and genera of Recent Stomatopod Crustacea, with diagnoses of six new families. Proceedings of the Biological Society of Washington, 93, 362-372.

Manning, R.B. (1981) Neotype selection for the stomatopod Squilla chiragra Fabricius, 1781. Crustaceana 40(2), $217-219$.

Manning, R.B. (1984) Gonodactyloideus cracens n.gen., n.sp., a new stomatopod crustacean from Western Australia. The Beagle, Occasional Papers of the Northern Territory Museum of Arts and Sciences, 1, 83-86.

Manning, R.B. (1995) Stomatopod Crustacea of Vietnam: the legacy of Raoul Serène. Crustacean Research, Special number 4, $1-339$.

Manning, R.B. \& Bruce, A.J. (1984) Erythrosquilla megalops, a remarkable new stomatopod from the western Indian Ocean. Journal of Crustacean Biology, 4(2), 329-332.

Manning, R.B., \& Camp, D.K. (1993) Erythrosquilloidea, a new superfamily, and Tetrasquillidae, a new family of stomatopod Crustaceans. Proceedings of the Biological Society of Washington, 106, 85-91.

Manning, R.B., \& Chan, T.-Y. (1997) The genus Faughnia from Taiwan, with the description of a new species (Stomatopoda: 
Parasquillidae). Journal of Crustacean Biology, 17, 546-554.

Manning, R.B. \& Lewinsohn, Ch. (1981) Selection of a Neotype for Cancer falcatus Forskål, 1775 (Stomatopoda). Crustaceana, 41(3), 314-316.

Manning, R.B. \& Reaka, M.L. (1981a) Gonodactylus aloha, a new stomatopod crustacean from the Hawaiian Islands. Journal of Crustacean Biology, 1(2), 190-200.

Manning, R.B. \& Reaka, M.L. (1981b) Gonodactylus siamensis, a new stomatopod crustacean from Thailand. Proceedings of the Biological Society of Washington, 94(2), 479-482.

Manning, R.B. \& Reaka, M.L. (1982) Gonodactylus insularis, a new stomatopod crustacean from Enewetak Atoll, Pacific Ocean. Proceedings of the Biological Society of Washington, 95, 347-351.

Miers, E.J. (1880) On the Squillidae. Annals and Magazine of Natural History, 5, 1-30, 108-127.

Miers, E.J. (1884) Crustacea. In: Report on the zoological collections made in the Indo-Pacific Ocean during the voyage of H.M.S. "Alert," 1881-2, pp. 178-322, 513-575, pls. 18-35, 46-52.

Milne Edwards, H. (1837) Histoire naturelle des Crustacés,comprenant l'anatomie, la physiologie et la classification de ces animaux, 2, 1-532. Atlas, 32 pp, pls. 1-14, 14 bis, 15-25 bis, 26-42. Roret, Paris.

Moosa, M.K. (1982) Faughnia serenei, new species, a stomatopod from the South China Sea. Journal of Crustacean Biology, 2, 600-604.

Moosa, M.K. (1986) Stomatopod Crustacea. Résultats du Campagnes MUSORSTOM I \& II Philippines, 2. Mémoires du Muséum national d'Histoire naturelle, Paris, series A, Zoologie, 133, 367-414, pl. 1.

Moosa, M.K. (1989) Some stomatopods (Crustacea: Stomatopoda) from Japanese waters, with description of a new species. Bulletin of the National Science Museum, Tokyo, series A, 15, 223-229.

Moosa, M.K. (1991). The Stomatopoda of New Caledonia and Chesterfield Islands. In: Richer de Forges, B. (Ed.), Le benthos de fonds meubles des lagons de Nouvelle-Calédonie, 1, 149-219. Editions de l'ORSTOM, Paris.

Naiyanetr, P. (1987) Two new stomatopod crustaceans from Thailand with a key to the genus Manningia Serène, 1962. Crustaceana, 53(3), 237-242.

Odhner, T. (1923) Indopazifiche Stomatopoden. Göteborgs Kungliga Vetenskaps-och Vitterhets-Sämhalles Handlingar, 27(4), $1-16$, pl. 1.

Osawa, M., Mitsuhashi, M. \& Takeda, M. (2004) Discovery of the type specimen of Lysiosquilla crassispinosa Fukuda, 1909 (Crustacea: Stomatopoda) and Fukuda's stomatopod specimens. Benthos Research, 59, 1-10.

Pocock, R.I. (1893) Report upon the stomatopod crustaceans obtained by P. W. Bassett-Smith, Esq., Surgeon R. N., during the cruise, in the Australian and China seas, of H.M.S. "Penguin," Commander W. U. Moore. Annals and Magazine of Natural History, series 6, 11, 473-479, pl. 20B.

Roxas, H.A. \& Estampador, E. (1930) Stomatopoda of the Philippines. Natural and Applied Science Bulletin, University of the Philippines, 1, 93-131.

Schmitt, W.L. (1931) Chinese Stomatopoda collected by S.F. Light. Lingnan Science Journal, 8, 127-155. (Dated 1929, printed 1931).

Schmitt, W.L. (1940) The stomatopods of the west coast of America, based on collections made by the Allan Hancock Expedition, 1933-38. Allan Hancock Pacific Expeditions, 5, 129-225.

Schotte, M. \& Manning, R.B. (1993) Stomatopod Crustacea from Tobago, West Indies. Proceedings of the Biological Society of Washington, 106, 566-581.

Serène, R. (1954) Observations biologiques sur les stomatopodes. Mémoires de l'Institut Océanographique de Nhatrang, 8, 1-93, pls. 91-10.

Souverbie, S.M. (1869) Diagnoses de mollusques inédits provenant de la Nouvelle-Calédonie. Journal de Conchyliologie, 17, 416-421.

Utinomi, H. (1956) Coloured illustrations of sea shore animals of Japan. Hoikusha, Osaka, i-xviii, 1-167, pls 1-64, figs. 1-44.

White, A. (1849) Description of two new species of Crustacea. Proceedings of the Zoological Society of London 15, 144, pl. 6 (also published in The Annals and Magazine of Natural History, series 2, 4, 381-382, 1849) (Dated 1848, printed 1849).

White, A. (1861) Descriptions of two species of Crustacea belonging to the families Callianassidae and Squillidae. Proceedings of the Zoological Society of London 1861, 42-44, pls. 6, 7.

Wood-Mason, J. (1875) (On some new species of stomatopod Crustacea). Proceedings of the Asiatic Society of Bengal 1875, 231-232 (untitled).

Wood-Mason, J. (1895) Figures and descriptions of nine species of Squillidae from the collection of the Indian Museum. Indian Museum, Calcutta, pp. 1-11, pls 1-4. 